\title{
Exploring Interpersonal Metafunction in an Electioneering Campaign Speech from Measuring Time (Helon Habila)
}

Innocent Sourou Koutchade $^{1 *}$, Servais Martial Akpaca ${ }^{2}$, Dieu-Donné Awoyodo ${ }^{3}$

${ }^{1,2,3}$ Abomey-Calavi University, Benin

DOI: $10.36348 /$ sijll.2020.v03i12.003

| Received: 03.12.2020 | Accepted: 16.12.2020 | Published: 20.12 .2020

*Corresponding author: Innocent Sourou Koutchade

\section{Abstract}

This study builds on the interpersonal meaning strand of the Systemic Functional Linguistics to highlight the suasive power of human language. In itemizing Lamang's electioneering campaign speech via such toolkits as mood, modality and personal pronouns, this paper employs a qualitative technique. It finds that the avalanche of mood types used by Lamang is made up of declarative clauses, which are echoed to convey information and convince the audience with positive facts. As to modal verbal operators, they are used to evince the speaker's adamant determination, and his unflinching commitment to move the whole country forward out of the dark ages and also build up his authority and selfishness. The prominent application of personal pronouns namely: "we" and "you" - "we" patterns, is meant to create an intimate dialogic style which can shorten the distance between the speaker and the audience, weaken the power and maintain a reliant and equal relationship between them. This greatly helps to persuade the addressees. Overall, this paper attempts to set into the fore the orator's communicative alertness as he to shifts from braggardism or boastfulness to opportunistic humility depending on the context.

Keywords: Speech, Interpersonal metafunction, mood, modality, personal pronoun.

Copyright () 2020 The Author(s): This is an open-access article distributed under the terms of the Creative Commons Attribution 4.0 International License (CC BY-NC 4.0) which permits unrestricted use, distribution, and reproduction in any medium for non-commercial use provided the original author and source are credited.

\section{INTRODUCTION}

Commonly admitted as means of social communication, language - typically the human type bears a magnetic power. For Crystal [1], it is "the concrete of speaking in a given situation", which alludes to the Saussurean concepts of Parole or Performance. As to Halliday and Webster [2], language is "a systemic resource for making and exchanging meaning." Focusing on its interactional potential, Wardhaugh [3] claims that "every language is a system which allows its speakers to interact with each other". Thus, in a sociopolitical marketing trend, it can alertly be wielded to bamboozle people, numb their mind and entice them to do somebody's will. The very fact is pretty well substantiated in Helon Habila's language through Measuring Time. Indeed, through his Lamangcharacter, he has variably demonstrated in many ways how language can [function to] impact and alter people's psyche or mental set-up in the course of electoral campaign.

In fact, this paper leans on the interpersonal strand of the Hallidayan linguistics to scrutinize Lamang's electioneering campaign speech. According to Halliday [4], it is through the interpersonal
Metafunction that users of language establish, negotiate and assume their position in social relationships, and it is concerned with clauses as exchanges. Moreover, the interpersonal metafunction of a speech represents the way the addresser and the audience interact, the way they use language to establish and maintain relations with each other, to influence their behavior, to express their own viewpoints on things etc. And thus, a speech becomes a rich, multifaceted phenomenon that can be explored from different points of view. The realization of interpersonal meanings or Function hooks to such instrumental tools as Mood, modality and deictic forms to itemize Habila's speech in proving the suasive power of language.

\section{Theoretical Background and Literature Review}

Language is structured to realize three metafunctions namely interpersonal meaning, ideational meaning and textual meaning [5-7]. Among these, the interpersonal metafunction is essentially concerned with enabling people to interact with each other, to establish and maintain relations in social vicinity, to influence behaviours, to express their own vision or standpoint on things and to influence the mindset of their speech partners. The analysis of the interpersonal metafunction revolves around such foci as Mood, modality and 
deictic forms. Mood is the core of interpersonal function in conversational analysis. It is often influenced by the running tenor of discourse and the degree of intimacy binding interactants [8]. As to modality system, Halliday [5] defines it as the intermediate degree between the positive and negative poles. It indicates both the speaker's attitude or assessment towards the discourse and the power relationship between the interactants. It is a twofold concept made up of Modalization and Modulation. My exploration of deictic forms is limited to the persontype, involving personal pronouns and their anamorphous. As argued by Halliday and Metthiessen [5], interpersonal meanings are also embodied in the person system. In studying interpersonal meanings in speeches, some scholars have found that the choice of personal pronoun affects the relationship binding the speaker to the audience $[9,10]$. This insinuates that the choice of personal pronouns can indicate the intimacy between speech participants, reflecting whether the speaker has some precedence over his/her audience or not. In the literature, a great number of papers and books on interpersonal analysis have been published. In this regard, the following articles can be refered to as a critical perspective.

Ye's [11] “The Interpersonal Metafunction Analysis of Barack Obama's Victory Speech" is demonstrative of how the American President's verbal power operates on his citizens. It shows how the orator conveys his information home to his audience and convinces them with positive facts. His use of modal operators as well as the recurrent application of the inclusive we-pronoun has helped to infuse attractive affection into the audience while the you-pronoun functions to maintain his authority over the audience by grapping some hegemonic distance from the mass populace. This discursive style shows that the communicator is an alert orator.

Ayoola [12] in his study has attempted to present interpersonal analysis of political advertisements. The analysis reveals that there is no one-to-one correspondence between the lexicogrammar and interpersonal meaning of a clause. The study has also revealed that the attitude and opinion of the speakers in political adverts are covertly indicated neither by the use of modal verbal operators, nor by mood adjuncts but by the lexical choices as well as grammatical structures that refect the socio-economic and political context of the adverts. Besides, the study has shown that the interpersonal meaning of a structural choice is not determined by the lexico-grammar but rather by contextual factors. Eventually, has Ayoola concluded that the analysis conducted in his study would enhance a better understanding of political advertisements from an interpersonal metafunction perspective.

Al-Sa'ati and Khalaf [13] have dealt with "A Critical Discoursal Analysis of Obama's Political
Speech at Cairo University". This study aims at showing the discoursal structure and linguistic features of president Obama's speech within the framework of functional linguistics. The study has come up with some conclusions that validate the five hypotheses raised at the very beginning of the work. According to the model adopted, the results show that Obama has made use of the transitivity choices in the use of clauses. Thus, he has used verbs which express a relational process, a process of being, more than other verbs. This means that he focuses on the relationship between the traditional ideals and modern beliefs. His aim in using this process is to create a very positive image of himself in the mind of the audience. As for circumstances, he is more interested in using the circumstance of location, both spatial and temporal. $\mathrm{He}$ has also used the circumstantial of reason. It seems that he has wanted to make his account more objective by providing the information to the audience in spatial and temporal terms. The same can be said about his use of the circumstance of reason. In addition, Obama's speech is characterized by simplicity. In other words, he tends to use simple words and short positive sentences. Consequently, his language is easily understood; a fact which has shortened the distance between him and his audience. Furthermore, the first person pronouns (weus) are the most frequently used. Using this pronoun, no doubt, shortens the distance between the speaker and the audience, regardless of their age, social status, profession, etc. It includes both the speaker and the listener, and thus, it makes the audience feel close to the speaker and to his points. The analysis also shows a high tendency to using positive modality rather than negative. Finally, the study reveals that Obama's speech involves words of less in offence as well as expressions that have metaphorical senses. Indeed, he has succeeded in making his audience understand and accept his views more easily. In so doing, he builds their confidence in him. He has planted the seedlings of his points in the hearts of his audience. So, he has brilliantly succeeded in persuading and influencing them to support his policy. This is actually how the genius of politicians functions to use honey-like words so as to set the required relational climate for gaining the confidence of their population.

In a move to critically analyze the use of modal auxiliaries in Nigerian political manifestoes, Taiwo [14] has emphasized their ideological use by Nigerian politicians in their electioneering campaign manifetoes; those policy documents designed to elicit fovourable political support from the electorate. The study has revealed that modal auxiliaries such as 'will', 'shall', 'must', 'can', etc. are used by the politicians in two manifestoes for persuasion, obligation, to make promises, demonstrate political will / commitment, and solicit public support and commitment. He has concluded that his study averred that modals are not just linguistic elements, but most importantly, political devices and ideological tools in political discourses. 
They are used to accentuate specific aims and themes in Nigerian political rhetoric.

Yongbin [15], has written an article on interpersonal function of presidential speeches. This paper applies Halliday's Systemic Functional Grammar to the study of interpersonal function in either of the two presidential speeches delivered by Barrack Obama and George W. Bush. It is found that there are several features in their presidential speeches. With respect to mood choice, declaratives account for $98,31 \%$ and imperatives for 1,69\%. Explicit subjective modalization is widely employed. These dominant features are closely connected to the communicative purpose of presidential speeches. This study proves that the theoretical framework of interpersonal function can be applied to the study of political discourse. It also deepens our understanding of the interpersonal function in presidential speeches and thus provides a new perspective in the study of political discourse. The author finds the following areas which could be promising and fruitful. The first one is the comparative study of interpersonal function of presidential speeches between the U.S. president and the Chinese president. It can deepen our understanding of presidential speeches. Secondly, due to the limit of time, the present paper only investigates mood and modality in their construction of interpersonal function. Therefore, further study of interpersonal function based on presidential speeches can be approached from the other two aspects, namely, personal pronouns and appraisal system. Hopefully, if these two aspects could be covered, the whole picture of interpersonal functions in presidential speeches could be brought to their full light.

Yang [16] has attempted to study the interpersonal Metafunction analysis of Barak Obama's inaugural speech. Following the Systemic Functional Grammar, this paper, in making a qualitative analysis and quantitative analysis, carries on a tentative interpersonal Metafunction analysis of Barack Obama's Inaugural Address from the perspective of Interpersonal Metafunction. In the process of a detailed analysis, this paper focuses on the Interpersonal roles, Mood and Modality system at the level of interpersonal function. The study finds that the plural forms of the first person are mostly used, declarative clauses have an absolute advantage, and the medium and low modal auxiliaries appear most frequently in Obama's address, which aims to help readers understand and evaluate the speech regarding its suitability. In so doing, it helps to provide some guidance for readers to improve their speech delivering skills.

In summary, this research shows that, from the perspective of the interpersonal Metafunction, positive declarative clauses dominate Barack Obama's Inaugural
Address; imperative clauses are in the second position; "will" "can" and "must" turn up frequently as modal verbal operators that corrupt or denature their speech. The first personal pronoun and its anamorphous turn up mostly in Barack Obama's Inaugural Address, the second personal pronoun "you" comes next. This paper can provide some guidance for readers to make better speeches as follows: (1) Positive declarative clauses are recommended to convey as many messages as possible to the audience and convince them with fact. (2) Appropriate application of imperative clauses is useful in making persuasion and suggestion. (3) Modal verbal operators with the higher or highest modal commitment can show the addresser's firm determination to finish the task, and "can" is helpful to encourage the audience to have confidence in their ability. (4) Choosing "We" to be the personal pronoun and applying "we"-"you""we" pattern can help to create an intimate dialogic style and shorten the distance between the addresser and the audience, which can further persuade the audience to share the same proposal of the addresser.

Shakila [17], in his study, has attempted to present an analysis of interpersonal metafunction in public speeches: a Case Study of Nelson Mandela's Presidential Inaugural Speech. By analyzing Nelson Mandela's presidential inauguration speech at Pretoria on May 10, 1994, this paper tries to conceptualize how interpersonal metafunction within the theoretical framework of Systemic Functional Grammar (SFG), a form of grammatical description pioneered by Michael Halliday, investigates into a language from a social semiotic approach. The analysis involves differences in the distribution of mood, modality, personal pronoun and other lexical features. The findings reveal that the architecture of Mandela's speech achieved his political purpose and fulfilled as well its interpersonal meaning not only by corresponding with its lexico-grammar but also by considering the contextual factors such as the need to reflect over the economic and socio-political situation of the country at that time.

This paper takes Nelson Mandela's presidential inauguration speech as a sample to elucidate the role of interpersonal metafunction in a public speech. It can be noticed that in this speech, the use of mood and personal pronoun outweighs the use of modals and rhythmic lexical features; but all together, they work within the same frame to explicate the speaker's interpersonal metafunction. From the above discussion, we can sum up that different uses of mood, modals, personal pronouns and rhythmic features of words can convey different levels of interpersonal meaning: different status, purpose, meaning and relationship between the speaker and the audience.

\section{The Interpersonal Metafunction Analysis of Lamang Electioneering Campaign Speech} This involves the analysis of mood, modality and pronoun 


\section{Mood Analysis in the Selected Extracts}

The mood analysis consists in the identification and description of mood, modality and personal pronoun.

\section{Identification of Mood, Modality in Extract}

It is worth giving the keys used to distinguish the functional constituents in the clauses identification.

\section{Keys:}

$\mathrm{S}=$ Subject, $\mathrm{F}=$ Finite, $\mathrm{Fn}=$ negative, $\mathrm{Fms}=$ Modalized, $\mathrm{Fml}=$ Modulated, $\mathrm{P}=$ Predicator, $\mathrm{PmL}=$ Modulated Predicator, $\mathrm{Pms}=$ Modalized Predicator

$\mathrm{F} / \mathrm{P}=$ fused Finite and Predicator, $\mathrm{Wh}=$ wh element, $\mathrm{wh} / \mathrm{s}$, wh/c, wh Ac fused wh element, $\mathrm{mn}=$ minor clause.

The Mood identification in Extract runs as follows: Lamang: 1. $\mathrm{I}(\mathrm{S})$ am $(\mathrm{F})$ talking $(\mathrm{P})$ of practical things $(\mathrm{Ac})$, 2.things that $(\mathrm{S})$ affect $(\mathrm{F} / \mathrm{P})$ our everyday life(C). 3.Take(P) water(C), for instance(Ac) ....'

Narrator: 4.Now $(A c)$ the $\operatorname{voice}(S)$ paused(F/P), 5.and(Aj) $\operatorname{Mamo}(\mathrm{S})$ imagined(F/P) his father $(\mathrm{C})$ looking at $(\mathrm{P})$ the faces $(\mathrm{C})$ seated $\operatorname{around}(\mathrm{P}) \operatorname{him}(\mathrm{C})$, one arm half(S) $\operatorname{raised}(\mathrm{F} / \mathrm{P})$, a smile(C) on his face(Ac), conscious $(\mathrm{Ca})$ of his importance $(\mathrm{C})$. "' 6 .Ninety percent of our people(S), in his face(Ac), in this local government $(\mathrm{Ac})$, are $(\mathrm{F})$ either full-time or part-time farmers $(\mathrm{Ca})$, 7.and(Aj) so(Aj) their greatest fear(S), our greatest fear $(\mathrm{S})$, is $(\mathrm{F})$ that of $\operatorname{drought}(\mathrm{Ca})$. 8.But(Aj) what if(wh/Aj) we $(\mathrm{S})$ assured(F/P) the people $(\mathrm{C})$ 9.that $(\mathrm{Aj}) \quad$ we $(\mathrm{S})$ could(Fms) solve(Pms) that $(\mathrm{C})$ ? 10.What if(wh/Aj) we(S) can(Fms) guarantee(Pms) that $(\mathrm{S})$ never(Ac) again $(\mathrm{Am})[\mathrm{C})$ 11.would(Fml) they(S) have to worry $(\mathrm{Pml})$ about $\operatorname{drought}(\mathrm{C})$, like that of 1973(Ac)? 12.“And(Aj) '76(Ac)," someone(S) contributed(F/P), 13."don't(Fn) forget(P) the droughtof 1976(C)."14."But(Aj) how(wh/Ac) can(Fms) you(S) do(Pms) that (C)? 15.Don't(Fn) tell(P) me(Ac) [you(S) will(Fml) hire $(\mathrm{Pml})$ rainmakers $(\mathrm{C})$ and $(\mathrm{Aj})$ witch doctors $(\mathrm{C})](\mathrm{C}) .$. 16.ha(Ao)- ha(Ao)." 17.This(S) was(F) Emmanuel Dogo's waggish contributrion $(\mathrm{Ca})$. Narrator:18.There(S) was(F) general laughter(C), deep male voices $(A c)$; 19.some of the laughter $(\mathrm{S})$ was $(\mathrm{F})$ forced $(\mathrm{P})$, calculating $(\mathrm{P})$. 20.Interpersed $(\mathrm{Ca})$ amid the male laughter(Ac) were(F) a few female voices $(\mathrm{Ca})$. 21.The widows $(\mathrm{mn} 2) .23$.There $(\mathrm{S})$ were $(\mathrm{F})$ three of them $(\mathrm{C})$ today $(\mathrm{Ac}) . \quad 24 . \mathrm{Mamo}(\mathrm{S}) \quad \operatorname{had}(\mathrm{F}) \quad \operatorname{seen}(\mathrm{P})$ them $(\mathrm{C})$ arrive $(\mathrm{P})$ separately $(\mathrm{Ac})$ earlier on $(\mathrm{Ac})$, , all(S) wearing $(\mathrm{P})$ their best buba(C) and(Aj) wrapper(Ca), their scarfs tall $(\mathrm{Ca})$ and $(\mathrm{Aj})$ stiff on their heads $(\mathrm{Ca})](\mathrm{C})$. 25.They $(\mathrm{S})$ 'd $(\mathrm{F})$ seated(P) discreetly $(\mathrm{Ac})$ on the outside of the semicircle of men $(\mathrm{Ac}),[\operatorname{or}(\mathrm{Aj})$ hovering $(\mathrm{P})$ by the door $(\mathrm{Ac})$, refilling $(\mathrm{P})$ empty water $\operatorname{cups}(\mathrm{C})$, going $\operatorname{out}(\mathrm{P})$ to the kitchen $(\mathrm{Ac})$ now and then $(\mathrm{Ac})$ to $\operatorname{return}(\mathrm{P})$ with plates of goat-head pepper $\operatorname{soup}(\mathrm{Ac})$ or $(\mathrm{Aj})$ some other $\operatorname{snack}(\mathrm{Ac}) \quad$ on a $\operatorname{tray}(\mathrm{Ac}), \quad \operatorname{batting}(\mathrm{P})$ eyelashes $(\mathrm{C})](\mathrm{C}) 26$. $[\operatorname{as}(\mathrm{Ac})$ they $(\mathrm{S})$ came in $(\mathrm{F} / \mathrm{P})](\mathrm{Ac})$, fingering $(\mathrm{P})$ their permed hair $(\mathrm{C})$ beneath their
scarves(Ac) 27.[as(Ac) they(S) passed(F/P) in front of the men $(A c)](A c), 28$. $[\operatorname{and}(A j)$ the $\operatorname{men}(S)$ would $(F m s)$ pause(Pms) momentarily(Ac) from their $\operatorname{arguments}(\mathrm{Ac})](\mathrm{C}) \quad 29 \cdot[\operatorname{as}(\mathrm{Aj}) \quad$ the women $(\mathrm{S})$ passed(F/P), to savor $(\mathrm{P})$ the whiff of soap and perfume - and $\operatorname{soup}(\mathrm{C})](\mathrm{Ac})$. 30.The three women $(\mathrm{S})$ were $(\mathrm{F})$ the remainders $(\mathrm{Ca})$ from the larger group of widows(Ac) 31.[who(wh/S) had(F) hovered(P) hopefully(Ac) around Lamang(Ac) after his wife's death $(\mathrm{Ac})](\mathrm{C})$. 32.On days like this(Ac) they(S)'d(F) politely(Ac) [but(Aj) firmly(Ac) take over (P)the kitchen $(\mathrm{C})$ from Auntie Marina(Ac) to $\operatorname{cook}(\mathrm{P})$ for the $\mathrm{TV}$ viewers(Ac) and $(\mathrm{Aj})$ the politicians $(\mathrm{Ac}), \operatorname{hoping}(\mathrm{P})$ by this $(\mathrm{Ac})$ to $\operatorname{catch}(\mathrm{P})$ the elusive $\operatorname{Lamang}(\mathrm{C})](\mathrm{C})$.

Lamang: 31. 'No'(Ap). No rainmakers(Ap),[Excl1]"

Narrator: 32.Lamang $(\mathrm{S})$ resumed(F/P), his voice $(\mathrm{C})$ almost curt $(\mathrm{Ac})$, emphasizing $(\mathrm{P})$ the seriousness of his proposal(C),33.but(Aj) of course (Am) there(S)'d(Fms) be(Pms) a small smile(C) on his lips(Ac) to acknowledge $(\mathrm{P})$ the humor $(\mathrm{C})$ in the last question(Ac).

Lamang: 34."I(S) am(F) a practical man(Ca), 35.I(S) always (Am)think(F/P) positive (Am). 36.Look at $(\mathrm{P})$ $\mathrm{me}(\mathrm{C})$, today $(\mathrm{Ac})$ 37.I(S) am $(\mathrm{F})$ the biggest cattle merchant $(\mathrm{Ca})$ in this state(Ac). 38.I(S) $\operatorname{saw}(\mathrm{F} / \mathrm{P})$ the opportunity $(\mathrm{C})$ a long time $\operatorname{ago}(\mathrm{Ac})$ before anyone else(Ac), 39.I $(\mathrm{S})$ saw $(\mathrm{F} / \mathrm{P})$ the big demand(C) for beef(Ac) in the densely populated coastal cities(Ac), 40.and $(\mathrm{Aj})$ how $(\mathrm{Ac})$ people(S) there $(\mathrm{Ac})$ were $(\mathrm{F})$ willing $(\mathrm{Ca})$ to $\operatorname{pay}(\mathrm{F})$ almost anything $(\mathrm{C})$ to $\operatorname{get}(\mathrm{P})$ good meat $(\mathrm{C})$. 41.I(S) $\operatorname{saw}(\mathrm{F} / \mathrm{P})$ what(C) that $(\mathrm{S})$ meant $(\mathrm{F} / \mathrm{P})$ in business terms $(\mathrm{Ac})$, 42.I(S) did $\operatorname{not}(\mathrm{Fn})$ hesitate $(\mathrm{P})$, 43.I $(\mathrm{S})$ seized $(\mathrm{F} / \mathrm{P})$ the opportunity $(\mathrm{C})$. 44.That $(\mathrm{S})$ is $(\mathrm{F})$ the kind of $\operatorname{approach}(\mathrm{C})$ 45.I(S) want $(\mathrm{F} / \mathrm{P})$ to bring $(\mathrm{P})$ to politics $(\mathrm{Ac})$, to our party $(\mathrm{Ac})$. 46. Supply and demand[mn2]. 47.I $(\mathrm{S})$ am $(\mathrm{F})$ going to use $(\mathrm{P})$ the same formula $(\mathrm{C}): 48 . \operatorname{get}(\mathrm{P})$ water $(\mathrm{C})$ from where $(\mathrm{Ac}) \quad[\mathrm{it}(\mathrm{S})$ is $(\mathrm{F})$ abundant $(\mathrm{Ca})](\mathrm{C})$ 49.and(Aj) transport $(\mathrm{P})$ it $(\mathrm{C})$ to where $(\mathrm{Ac})[\mathrm{it}(\mathrm{S})$ is $(\mathrm{F}) \operatorname{scarce}(\mathrm{Ca})$.

Narrator: 50.Lamang $(\mathrm{S})$ allowed $(\mathrm{F} / \mathrm{P})$ the murmurs $(\mathrm{C})$ to go on $(\mathrm{P})$ for a while $(\mathrm{Ac})$, 51.and(Aj) then $(\mathrm{Aj})$ he $(\mathrm{S})$ cleared(F/P) his voice $(\mathrm{C})$.

Lamang: 52. "Gentlemen-and ladies(Av), of course(Am), ha(At)-ha(At)! [Excl2]-53.I(S) can(Fms) hear(P) you $(\mathrm{C})$ asking $(\mathrm{P}):$ 54.But(Aj) how(Ac) can(Fms) he(S) do(P) that (C), 55.could(Fml) you(S) transport $(\mathrm{Pms})$ water $(\mathrm{C})$ in trucks $(\mathrm{Ac})[\operatorname{like}(\mathrm{Ac})$ you $(\mathrm{S})$ transport $(\mathrm{F} / \mathrm{P})$ cattle $(\mathrm{C})](\mathrm{Ac}), \quad[\operatorname{and}(\mathrm{Aj})$ even if $(\mathrm{Am})$ you $(\mathrm{S}) \quad$ could(Fml $)], 56 . \operatorname{could}(\mathrm{Fml}) \quad$ you(S) transport(Pml) enough(Ac) from your source(Ac) to supply $(\mathrm{P})$ a whole village $(\mathrm{C})$, a whole local government $(\mathrm{C})$, in time of $\operatorname{drought}(\mathrm{Ac})$ ? 57.Well(At), $\mathrm{I}(\mathrm{S})$ have(F/P) a practical, scientific answer(C), not black magic and(Aj) witchcraft(C) [like(Ac) some(S) here (Ac) may(Fms) want (Pms) to propose $(\mathrm{P})(\mathrm{C}) \ldots .$.

Narrator: 58.And(Aj) here $(A c)$ he $(S) \operatorname{paused}(F / P)$ to let(P) the $\operatorname{crowd}(\mathrm{C})$ appreciate $(\mathrm{P})$ [how $(\mathrm{Ac})$ he(S) had(F) cleverly $(\mathrm{Ac})$ turned(P) the joke on Emmanuel $\operatorname{Dogo}(\mathrm{C})$, before $(\mathrm{Ac})$ proceeding $(\mathrm{P})](\mathrm{Ac})$.

Lamang: 59.“As a businessman (Ac) I(S) travel(F/P) a $\operatorname{lot}(\mathrm{Ac}), 60$.and(Aj) on my travels(Ac) $\mathrm{I}(\mathrm{S}) \operatorname{meet}(\mathrm{F} / \mathrm{P})$ 
all kinds of people(C). 61.That(S) is(F) [how(Ac) $\mathrm{I}(\mathrm{S})$ came $(\mathrm{F} / \mathrm{P})$ to learn $(\mathrm{P})$ about reverse osmosis $(\mathrm{C})](\mathrm{Ac})$. 62.I(S) can(Fms) see(Pms) some of you(C) already $(\mathrm{Am})$ looking at $(\mathrm{P})$ your neighbors $(\mathrm{C})$ in puzzlement(Ac). 63.Don't(Fn) worry(P)[ImM5], 64.I(S) have(F) it(C) all(Ac) written down(P) here(Ac) 65.and(Aj) I(S)'ll(Fml) give(Pml) it(C) to you(Ac) to $\operatorname{read}(\mathrm{Ac})$ as soon as $(\mathrm{Ac}) \mathrm{I}(\mathrm{S})$ finish(F/P) speaking $(\mathrm{P})$. 66.But(Aj) don't be(Fn) overwhelmed(P) by the huge scientific term(Ac). 67.It(S) simply(Am) refers(F/P) to a process $(C)$ for purifying $(\mathrm{Ac}) \operatorname{salty}(\mathrm{C})$ or $(\mathrm{Aj})$ unclean water(C) from the sea $(\mathrm{Ac})$ and $(\mathrm{Aj})$ pumping $(\mathrm{P})$ it $(\mathrm{C})$ inland(Ac) in pipes(Ac), et cetera(At). 68. It $(\mathrm{S})$ is $(\mathrm{F})$ the same $\operatorname{system}(\mathrm{C}) \operatorname{used}(\mathrm{P})$ by $\operatorname{ships}(\mathrm{Ac})$ on the ocean $(\mathrm{Ac})$ when $(\mathrm{Aj})$ they $(\mathrm{S})$ need(F/P) fresh water $(\mathrm{C})$. 69.Imagine(P) if( $\mathrm{Aj})$ we(S) can(Fms) sink(Pms) our pipes(C) in the River Niger(Ac), or(Aj) in Lake Chad(Ac), or(Aj) even(Ao) in the Atlantic(Ac), and(Aj) using $(\mathrm{P})$ reverse osmosis $(\mathrm{C})[\mathrm{Excl} 2]$, 70.we(S)'ll(Fml) purify $(\mathrm{Pml})$ the water $(\mathrm{C})$, 71.[and(Aj) then $(\mathrm{Aj})$ we(S)'ll(Fml) use(Pml) giant engines(C) to $\operatorname{pump}(\mathrm{P})$ it(C) inland $(A c)[$ whenever $(A j)$ there $(S)$ is $(F)$ $\operatorname{drought}(\mathrm{C})$ in our region $(\mathrm{Ac})](\mathrm{Ac}),[\operatorname{or}(\mathrm{Aj})$ to store $(\mathrm{P})$ in our giant reservoirs(Ac) to use later(Ac) as(Ac) we(S) wish(F/P)](C). 72.Gentlemen(Av), this $(\mathrm{S})$ is $(\mathrm{F})$ the age of science and modernity $(\mathrm{C})$; 73.things $(\mathrm{S})$ like this $(\mathrm{Ac})$ are not(Fn) impossible $(\mathrm{Ca})$ if(Aj) we(S) have $(\mathrm{F} / \mathrm{P})$ the will $(\mathrm{C})$ and $(\mathrm{Aj})$ the money $(\mathrm{C})$. 74.This $(\mathrm{S})$ is $(F)$ the time $(A c)$ to move $(\mathrm{P})$ our whole country(C) and(Aj) our people(C) forward out of the dark ages(Ac). 75.Think(P) positive(Am). 76.Think(P). 77. supply(P) and(Aj) demand(P)".

Narrator:78.There $(\mathrm{S}) \quad$ was $(\mathrm{F}) \quad$ a long pause(Ac),79.and(Aj) then(Aj) $\operatorname{Mamo}(S) \operatorname{Heard}(F / P)$ one pair of hands(C) coming(P)together(Ac), 80.and(Aj) soon(Ac) more hands(S) joined on(F/P). 81. $\mathrm{He}(\mathrm{S})$ could $(\mathrm{Fml})$ imagine $(\mathrm{Pml})$ the $\operatorname{men}(\mathrm{C})$ getting up(P) and(Aj) shaking(P) Lamang's hand(Ca), patting $(\mathrm{P}) \operatorname{him}(\mathrm{C})$ on the $\operatorname{back}(\mathrm{Ac})$, repeating $(\mathrm{P})$ the strange(C) but(Aj) impressive words "reverse osmosis"(C) with awe(Ac), and(Aj) the widows(S) basking $(\mathrm{P})$ in reflected glory $(\mathrm{Ac}) .82$. There $(\mathrm{S})$ was $(\mathrm{F})$ more clinking cutlery $(\mathrm{C})$ and $(\mathrm{Aj})$ glasses $(\mathrm{C})$, and $(\mathrm{Aj})$ then $(\mathrm{Aj})$ much later(Ac) the sound of footsteps $(\mathrm{C})$ 83.as(Aj) the men(S) left(F/P) for their cars(Ac) and $(\mathrm{Aj})$ the long drive $(\mathrm{C}) \operatorname{back}(\mathrm{Ac})$ to their homes(Ac). 84.The widows(S) remained(F/P) 85.and(Aj) Mamo(S) heard $(\mathrm{F} / \mathrm{P})$ their soft, syrupy voices $(\mathrm{Ca})$ outdoing $(\mathrm{P})$ each other(C) in congratulating $(\mathrm{P}) \operatorname{Lamang}(\mathrm{C})$ on his brilliant speech $(\mathrm{Ca})$. 86. Outside (Ac), the $\operatorname{sun}(\mathrm{S})$ would (Fms) be (Pms) slow(Ac) over the hills(Ac), setting(P). 87.It $(\mathrm{S})$ was $(\mathrm{F}) \operatorname{dark}(\mathrm{Ca})$ in the $\operatorname{room}(\mathrm{Ac})$ already $(\mathrm{Ac})$, 88. but(Aj) Mamo(S) didn't(Fn) bother(P) to turn on(P) the $\operatorname{light}(\mathrm{C}) 89$.there $(\mathrm{S}) \quad$ was $(\mathrm{F}) \quad$ something $(\mathrm{P})$ comforting $(\mathrm{P})$, cocoonlike(Ac), in the soft darkness $(\mathrm{C})$. 90. The women(S) should (Fms) be(Pms) heading off(P) to their lonely houses $(\mathrm{Ca})$ by now(Ac), 91.but(Aj) none of them $(\mathrm{S})$ wanted $(\mathrm{F} / \mathrm{P})$ to $\mathrm{be}(\mathrm{P})$ the first(C) to leave(P). 92.They(S) were(F) still(Am) gushing(P) nonchalantly(Ac), 93.but(Aj) beneath(Ac) their colored eyebrows $(\mathrm{C})$ they $(\mathrm{S})^{\prime} \mathrm{d}(\mathrm{Fms})$ be(Pms) keenly(Ac) watching(Pms) each other(C), 94.each $(\mathrm{S})$ waiting for $(\mathrm{P})$ the other $(\mathrm{C})$ to give in $(\mathrm{P})$ and $(\mathrm{Aj})$ $\operatorname{depart}(\mathrm{P})$ first(Ac). 95.And(Aj) Lamang(S) would(Fms) be(Pms) lapping(P) it(C) all up(Ac), 96.sprawled on $(\mathrm{F} / \mathrm{P})$ the central sofa $(\mathrm{Ac})$, a woman $(\mathrm{C})$ on each $\operatorname{side}(\mathrm{Ac})$ of $\operatorname{him}(\mathrm{Ca})$ 97.the unlucky third(S) would(Fms) be(Pms) alone(Ac) on the seat(Ac) facing $(\mathrm{P})$ the $\operatorname{sofa}(\mathrm{C})$, [leaning forward $(\mathrm{P})$ as much as possible $(\mathrm{Ac})$, reaching $\operatorname{out}(\mathrm{P})$ to $\operatorname{pat}(\mathrm{P}) \operatorname{Lamang}(\mathrm{C})$ on the knee(Ac) with each sentence(C), with each burst of laughter(C)](C).98.Mamo(S) sometimes (Am) wondered(F/P) 99.if(Aj) his father(S) had(F/P) $\operatorname{sex}(\mathrm{C})$ with the widows $(\mathrm{Ca})$. 100.They $(\mathrm{S})$ were $(\mathrm{F})$ allowed(P) in his father's bedroom $(\mathrm{Ca}) \operatorname{openly}(\mathrm{Ac})$, to clean $(\mathrm{P})$, sometimes(Am) to $\operatorname{chat}(\mathrm{P})$ 101.but(Aj) they $(\mathrm{S})$ always $(\mathrm{Am}) \operatorname{left}(\mathrm{F} / \mathrm{P})$ the $\operatorname{door}(\mathrm{C})$ open $(\mathrm{P}), 102$. as if $(\mathrm{Aj})$ to $\operatorname{say}(\mathrm{P}), \operatorname{See}(\mathrm{P})$, nothing indecent $(\mathrm{S})$ is $(\mathrm{F})$ taking $(\mathrm{P})$ place $(\mathrm{Ac}) .103$. But $(\mathrm{Aj})$ there $(\mathrm{S})$ were $(\mathrm{F})$ days(Ac) 104.when $(\mathrm{Ac})$ he(S) had(F) $\operatorname{returned}(\mathrm{P})$ 105.and $(\mathrm{Aj})$ found $(\mathrm{F} / \mathrm{P})$ the $\operatorname{door}(\mathrm{C}) \operatorname{shut}(\mathrm{P})$, and $(\mathrm{Aj}) \mathrm{a}$ woman's voice $(\mathrm{Ca})$ inside $(\mathrm{Ac})$ talking $(\mathrm{P})$ in low tones $(\mathrm{C})$ to his father $(\mathrm{Ca})$. 106.Yet $(\mathrm{Ac})$ there $(\mathrm{S})$ was $(\mathrm{F})$ something $(\mathrm{C})$ almost asexual(Ac) about these women $(\mathrm{Ca})$ in their forties and fifties $(\mathrm{Ca})$ battling $(\mathrm{P})$ loneliness $(\mathrm{C})$ and $(\mathrm{Aj})$ midwife crisis $(\mathrm{C})$ with powdered faces $(A c)$ and $(A j)$ painted $\operatorname{lips}(\mathrm{Ac})$ and $(\mathrm{Aj})$ cheap perfumes $(\mathrm{Ac}) \operatorname{sent}(\mathrm{P})$ to them $(\mathrm{Ca})$ by their grown-up daughters $(\mathrm{Ca})$ married($(\mathrm{P})$ to civil servants $(\mathrm{Ca})$ in the city $(\mathrm{Ac})$, trying $(\mathrm{P})$ so hard $(\mathrm{Ac})$ to capture $(\mathrm{P})$ the fading bloom $(\mathrm{C})$ in their lives(Ca) 107.before(Ac) it(S) finally(Ac) fell of(F/P) the stem(C). 108.Suddenly(Ac) he(S) felt $(\mathrm{F} / \mathrm{P})$ an $\operatorname{urge}(\mathrm{C})$ to get $\mathrm{up}(\mathrm{P})$, to go out $(\mathrm{P})$ and $(\mathrm{Aj})$ feel(P) the $\operatorname{cold}(\mathrm{Ca})$, bracing $(\mathrm{P})$ harmattan wind $(\mathrm{C})$ in his face $(\mathrm{Ca})$. 109. His mouth $(\mathrm{S}) \operatorname{felt}(\mathrm{F} / \mathrm{P})$ 110.as if(Aj) it(S) were(F) stuffed(P) full(Ac) or(Aj) cow dung(Ac). 111.He(S) got off(F/P) the $\operatorname{bed}(\mathrm{C})$ 112.and $(\mathrm{Aj})$ as $(\mathrm{Ac})$ he(S) stood $\mathrm{up}(\mathrm{F} / \mathrm{P})$ 113.he(S) felt(F/P) the floor(C) move(P) 114.and(Aj) he(S) had to(Fms) press $(\mathrm{Pms})$ against the wall $(\mathrm{Ac})$ to steady $(\mathrm{P})$ $\operatorname{himself}(\mathrm{Ca})$, 115.then $(\mathrm{Aj})$ the $\operatorname{vertigo}(\mathrm{S}) \operatorname{passed}(\mathrm{F} / \mathrm{P})$ 116.and $(A j)$ he $(S)$ went out(F/P) $[$ he $(S) \operatorname{passed}(F / P)$ the living $\operatorname{room}(\mathrm{Ac})$ quickly $(\mathrm{Ac})$, avoiding $(\mathrm{P})$ his father's $\operatorname{gaze}(\mathrm{Ca})$, smiling $(\mathrm{P})$ politely in $\operatorname{response}(\mathrm{Ac})$ to the chorus of endearments $(\mathrm{C})$ from the women $(\mathrm{Ca})]$ :

Lamang: 117."Hello(mn), Twin(Ap), 118. come(P) and (Aj) say(P) hi(C) .see(P) how thin(Ac) you(S) $\operatorname{look}(\mathrm{F} / \mathrm{P}) \ldots$ 119. This(S) was (F) Rabi(C), a teacher(Ap) in the Women's Teachers' College(Ac).

Narrator: 120. The rouge and powder(S) on her cheeks $(\mathrm{Ca}) \operatorname{made}(\mathrm{F} / \mathrm{P})$ her $\operatorname{look}(\mathrm{Ca})$ jaundiced(P). 121.She(S) was(F) seated(P) on Lamang's right(Ac), pressing $(\mathrm{P})$ her left breast $(\mathrm{Ca})$ against his $\operatorname{arm}(\mathrm{Ac})$, pulling away $(\mathrm{P})$ discreetly(Ac) Mamo's entrance $(\mathrm{Ca})$.

Doris: 122. "Your hair(S) is(F) so bushy(Ac), Twin(Ap), 123.you(S) need(F/P) a haircut(C), dear(Av)..."

Narrator:124.This(S) was(F) Doris(Ca), the eldest of the widows $(\mathrm{Ca})$, in her early fifties $(\mathrm{Ca})$, her twisted mouth $(\mathrm{Ca})$ hinting at(P) a bitter past(Ac), an unhappy 
present $(\mathrm{Ac})$; 125.she $(\mathrm{S})$ had(F) three children $(\mathrm{C})$, all in their twenties(Ca). 126.She $(\mathrm{S})$ was $(\mathrm{F})$ the unlucky third $(\mathrm{C})$ in the single seat $(\mathrm{Ac}) \operatorname{directly}(\mathrm{Ac})$ facing $(\mathrm{P})$ Lamang(C). 127.Her severe headscarf(S) $\operatorname{made}(\mathrm{F} / \mathrm{P})$ her look $(\mathrm{Ca})$ even older $(\mathrm{Ac})$ than her age $(\mathrm{Ca})$; 128.her huge sagging breasts $(\mathrm{S})$ seemed $(\mathrm{F} / \mathrm{P})$ to be $(\mathrm{F})$ pulling $(\mathrm{P})$ her shoulders(Ca) downward(Ac).

Asabe: 129."Where(wh/Ac) have(F) you(S) been hiding(P), Twin(Av)...?” Narrator:130.This(S) was(F) Asabe(Ca), forty-five years old(Ac), mother of five children $(\mathrm{Ca})$. 131.She $(\mathrm{S})$ was $(\mathrm{F})$ the prettiest $(\mathrm{Ac})$ : petite(Ac) with long slender $\operatorname{arms}(\mathrm{Ca}) \operatorname{and}(\mathrm{Aj})$
surprisingly(Ac) firm-looking breasts $(\mathrm{Ca})$. 132.She(S) was(F) the shiest $(\mathrm{Ac})$, always (Am) lurking out(P) of sight $(\mathrm{C})$, letting $(\mathrm{P})$ the others $(\mathrm{C}) \operatorname{do}(\mathrm{P})$ the talking(C)133.while(wh/Ac) $\operatorname{she}(\mathrm{S}) \quad \operatorname{nodded}(\mathrm{F} / \mathrm{P})$ enthousiastically(Ac)[, 134.her $\operatorname{lips}(\mathrm{S})$ always(Am) $\operatorname{parted}(\mathrm{F} / \mathrm{P}), \operatorname{ready}(\mathrm{Ca})$ to laugh $(\mathrm{P})$ agreeably $(\mathrm{Ac})$.

\section{Statistics of Mood Types in the Extract}

The descriptive scrutiny of the excerpt under study has revealed the Mood data compiled in the statistic grid below:

Table-1: Distribution of Mood-types in the Extract

\begin{tabular}{|l|l|l|l|l|l|}
\hline \multirow{2}{*}{ Mood types } & \multicolumn{2}{|l|}{ Interactants } & \multirow{2}{*}{ Total } \\
\cline { 2 - 5 } & Lamang & Narrator & Doris & Assebe & \\
\hline Declaratives & $40(34.18 \%)$ & $70(59,82 \%)$ & $07(05.98 \%)$ & $00(0 \%)$ & $117(87.31 \%)$ \\
\hline Wh-Interrogative & $00(00 \%)$ & $00(0 \%)$ & $00(0 \%)$ & $01(100 \%)$ & $01(0.74 \%)$ \\
\hline Polar-interrogative & $05(100 \%)$ & $00(0 \%)$ & $00(0 \%)$ & $00(0 \%)$ & $05(03.73 \%)$ \\
\hline Exclamatives & $02(100 \%)$ & $00(0 \%)$ & $00(0 \%)$ & $00(0 \%)$ & $02(01.49)$ \\
\hline Imperatives & $08(100 \%)$ & $00(0 \%)$ & $00(0 \%)$ & $00(0 \%)$ & $08(05.97 \%)$ \\
\hline Modalized interrogatives & $00(0 \%)$ & $00(0 \%)$ & $00(0 \%)$ & $00(0 \%)$ & $00(0 \%)$ \\
\hline Minor clauses & $01(100 \%)$ & $00(0 \%)$ & $00(0 \%)$ & $00(0 \%)$ & $01(0.74 \%)$ \\
\hline Total/participant & $56(41.79 \%)$ & $70(52.23 \%)$ & $07(05.20 \%)$ & $01(0.74 \%)$ & $134(100 \%)$ \\
\hline
\end{tabular}

\section{Critical Discourse of the Findings}

This extract is made of 134 clauses allotted among Lamang, the narrator and Lamang's paramour Doris and Assebe. A care emphasis is made on mood types expressed by Lamang.

Out of the fifty-six of major clauses [in total], 40 clauses are declarative, taking up $34.18 \%$ of the speech functions involving clauses $\mathrm{N}^{\circ} 1,5,6,26,28$, 30, 32, 34, 41, among others. Lamang has used 08 $(16 \%)$ imperative clauses including such clauses 3,13 , 15,36 , among others. There are 03 interrogative clauses $(06 \%)$ encompassing clauses 10,11 and 14 , and only $2(04 \%)$ exclamatory clauses.

Overall, the figures in the table above show that the distribution of Mood types is sharply unbalanced. Declaratives are profusely used with a high percentage of $74 \%$. In sharp contrast, imperatives, interrogatives and exclamatives all together account for less than $26 \%$. The reason why declaratives have such a particularly high percentage is that the main communicative purpose of Lamang's speech is to give information. By way of instantiation, I may consider the following clauses:

1) "I am talking of practical things, things that affect our everyday life." $(1 ; 2)$

2) "I am the biggest cattle merchant in this state." (37)

3) "I saw the opportunity a long time ago before anyone else." (39)

4) Things like this are not impossible if we have the will and the money."(73)
From the illustrative clauses above, one can underline out that Lamang has chosen the declarative Mood type to give more information and explanation to his people. We should also bear in mind that what Halliday [5] refers to as the "multidimensional architecture of language" reflects the multidimensional nature of human experience and interpersonal relations. This is most obvious in speeches, particularly in a political one where to fulfill the mission it is vital for the speaker to give information and ask for service. Lamang has planned on the one hand to deliver some messages to the audience showing his political attitude and assumption. On the other hand, he tries to appeal to the audience and commits them to follow his instruction. Indeed, declarative clauses predominate in this political speech; imperative clauses come next. Interrogative and exclamative clauses are less used because they don't make a speech more solemn, more convincing and persuasive. With regard to the above, the prevalence of declarative clauses in Lamang's speech is instrumental in that they function as statements to give as much information as possible to the audience. The ontological mission of those declarative clauses is to inform the audience about Lamang's ability to tell what can be done to trigger the sustainable development of Nigeria. He alertly avoids to impose his own ideas upon his listeners. First, he strives to provide a full, clear and objective picture of the situation and then presents his own ideas about the critical situation of the country. In this quite seemingly democratic but essentially diplomatic presentation fashion, it is up to the listeners to accept his ideas, or not. Though the speech sounds free and democratic, it bears a behind-scene objective: that of sparkling the 
audience's mind and spurring them into lining up with his own plan, his political programme.

Although, the imperative mood covers a very small percentage of the speech, it bears sound communicative merits. For example, through the following clauses: "Take water for instance (3)", "Don't forget the drought of 1976 (13), “ “ Don't tell me you will hire rainmakers and witch doctors (16)" and "Look at me today; I am the biggest cattle merchant in this state" $(36,37)$ the addresser (Lamang) calls upon the audience for three reasons. Firstly, they should look backwards thinking about the havoc caused by water shortage. Secondly, Lamang invites his audience to rely on their own effort. Thirdly, he appeals to them to consider his speech as the only practical and noteworthy solution to their problems. Lamang therefore, inspires, uplifts and advises his audience to follow his instructions in order to get out of a difficult situation. He is not giving order directly but he is enlighting, persuading and arousing people's passion to dream, hope, believe and act in order to attain a bright blooming. The non-existence of the reversely suggestive format such as "let's" or "let us" shows that Lamang is aware of the different ways and means to ensure a quick welfare. He is appealing to his people to get out of their lethargy and act to change their own fate.

Besides, interrogative clauses are much less used in the speech. As a matter of fact, the few interrogative clauses such as "But what if we assured the people that we could solve that" (8), " what if we can guarantee that never again would they have to worry about drought, like that of 1973? (9), "But how can you do that"? (14) have been voiced by Lamang in his speech to draw his listeners' attention to the drawbacks caused by the 1973 drought, highlighting his ability to find ways out of this problem. Apparently, Lamang doesn't look forward to the audience's answers. His questions are not only used to attract people's attention as far as the drought is concerned, but also to emphasize it in order to make them think and persuade them to elect him because he is the right man who is able to help overcome the current difficulties.

\section{Modality Analysis of the Speech \\ Statistics of the Modality Types in the Extract}

Just like the previous mood case, the description of the speech permits to sort out the following modality aspects:

Table-2: Statistics of the use of modality in the Extract

\begin{tabular}{|l|l|l|l|l|l|}
\hline \multirow{2}{*}{ Modality types } & \multicolumn{2}{|l|}{ Interactants } & \multirow{2}{*}{ Total } \\
\cline { 2 - 5 } & Lamang & Narrator & Doris & Assebe & \\
\hline Modalisation & $06(54.54 \%)$ & $04(36.36 \%)$ & $01(09.09 \%)$ & $00(0 \%)$ & $11(50 \%)$ \\
\hline Modulation & $09(81.81 \%)$ & $02(18.18 \%)$ & $00(0 \%)$ & $00(0 \%)$ & $11(50 \%)$ \\
\hline Total per interactant & $15(68.18 \%)$ & $06(27.27 \%)$ & $01(04.54 \%)$ & $00(0 \%)$ & $22(100 \%)$ \\
\hline
\end{tabular}

\section{Critical Discourse of the Findings}

The different modality types are distributed among Lamang, narrator Doris and assebe. Altogether, participants have used 22 elements. As stated in the table, Lamang has echoed in his speech 15 (68.18\%) modality elements. These modality items are shared into modalisation and modulation respectively by an uneven allotment of 06 (54.54\%) occurrence rounds versus $9(81.81 \%)$.

A good command of the "situationally appropriate expression of modality enables the writer or speaker to address the intended audience with skill and exhibit a professional interpersonal competence" [18]. This claim has been substantiated in Lamang's speech where statistically 15 modal verb operators can be identified as presented in the table above. The use of these modal verbal operators does not follows any precise grammatical rules but grounds on prevailing situations or contexts. As a matter of, the use of the four (4) "will" has a dual role in the speech. "will" as a predicator of the future and"will" as a symbol of strong disapproval, wish, determination or commitment. Being a marker of the future tense, "will" is adopted twice in Lamang's election campaign speech. This can be shown in the following example:
"Imagine if we can sink our pipes in the river Niger, Or in Lake Chad, or in the Atlantic, and using reverse osmosis, we will purify the water and will use giant engines". Those two "will" in clauses $(70,71)$ predict how people can fight against water shortage in a near future if they take into account Lamang's proposal. Reversely, the two "will" in the following clauses: "Don't worry, I have it all written down here and I will give it to read as soon as I finish speaking" $(63,64$ and 65 ) and "Don't tell me you will hire rainmakers and witch doctors"(15) denote respectively, on the one hand, that Lamang appeases his audience by insisting he is not a liar. He has based his speech on practice or action rather than on theory or hypothesis, which signals his strong determination. On the other hand, through "will" in the second clause (15), Lamang shows his authority and his inclination to commit himself to solving water shortage concretely instead of calling for rainmakers or witch doctors. Thus, his projects sound quite assuring and realistic and owes nothing to superstition, which proves that he is a quite suasive communicator.

Altogether, as mentioned above, different scales of modal operators lead to different meanings. 
"Will", which represents a higher scale of modal commitment, evinces a higher degree of certainty about the validity of a proposition. Thus, the use of "will" in the clauses in question is effective in displaying Lamang's strong mind and keen desire to help his people overcome their series of difficulties and frustrations. At the same time, the modal operator "will" further confirms that more concrete actions will be taken in the future.

In the same vein, the use of "can" and "could" represents a low scale of modal commitment. The semantic meaning of these modals is to show one's ability to do something. So, by using these modal operators, Lamang, on the one hand, tries to persuade his listeners to believe in his dexterity and competence, relying as well on their own ability. On the other hand, Lamang is minimizing the gap between him and his fellow people. Here are typical examples: "but we could solve this problem" (9), "we can guarantee that never come again" (10), we can see sink our pipes in the river" (69). The modal operators "can" and "could" signal that Lamang is convincing his audience to believe in themselves, to be confident that they have the ability to do something. He is telling the listeners that it's time to move the whole country and people forward out of the dark ages.
The modal operator "may" used by Lamang in "I have a practical scientific answer, not a black magic and witchcraft like some here may want to propose" (57) is a supportive illustration of his commitment and his practical actions. He has used this "may" whose semantic meaning insinuates a probability, pointing to the other politicians who rely on black magic and witchcraft instead of practical scientific acts. Through this modality type, one can sense out that Lamang is a pragmatic man willing to take decisions and actions that are useful in practice, not just in theory. Another corroborative illustration is "would have to" in "what if you can guarantee that never again would they have to worry about drought like that of 1973 "(10,11). Here, this modality element functions to display a high commitment and Lamang's firm determination to halt drought which is a perilous disaster. He calls on his audience to have fixed and unshakable resolution since there is hope and chance to turn the darkest days into glaring light. Besides, the absolute negative usuality adverb "never" comes in to make the cunning contention more forceful. Now, how about the contributions of person deictic forms to the overall meaning of the extract?

\section{Analysis of Person Deictic Forms Statistics of the Person Deictic Forms}

Here again, data compiled in the following table derive from the descriptive study of the extract.

Table-3: Frequency of person deictic forms

\begin{tabular}{|l|l|l|l|l|l|l|l|l|l|}
\hline \multirow{2}{*}{$\begin{array}{l}\text { Deictic } \\
\text { forms }\end{array}$} & \multicolumn{4}{|l|}{ First person pronouns } & \multicolumn{2}{l|}{$\begin{array}{l}\text { Second } \\
\text { pronouns }\end{array}$} & \multicolumn{2}{l|}{ person } & \multicolumn{2}{l|}{ Third person pronouns } \\
\cline { 2 - 10 } & $\mathrm{I}$ & $\mathrm{We}$ & $\mathrm{Us}$ & Our & You & Your & s/he & They/them/their/it & \\
\hline $\begin{array}{l}\text { Occurrence } \\
\text { rounds }\end{array}$ & 20 & 8 & 0 & 7 & 6 & 1 & 1 & 2 & 45 \\
\hline Frequency & $44.44 \%$ & $17.77 \%$ & $00 \%$ & $15.55 \%$ & $13.33 \%$ & $02.22 \%$ & $02.22 \%$ & $04.44 \%$ & $100 \%$ \\
\hline
\end{tabular}

\section{Critical Discourse of the Findings}

As can be remarked, the first person pronoun makes up $77.77 \%$ of the total usage of personal pronoun system of which the inclusive plural "we" and its anamorphous "us" and "our" occupy $33.33 \%$, the first singular person "I" takes up to $44.44 \%$. The second person pronouns represent $15.55 \%$ and the third person ones come next, with $04.44 \%$.

Altogether, Lamang has echoed 45 person deictic forms in his speech. The first personal "I" has been used by Lamang to connot versatile meanings. By virtue of instantiation, the first of all consider the following clauses may be considered

- "I am talking of practical things, things that affect our everyday life" $(1,2)$

- "I am a practical man and I always think positive" $(34,35)$

- "I did not hesitate, I seized the opportunity" $(41,42)$
- "I am going to use the same formula to get water from where it is abundant and transport it to where it is scare." $(47,48,45)$

From the above clauses, it can be mentioned that the excessive application of "I" successfully describes Musa Lamang during the electoral campaign as the chairman of the state. In order to win and charm the soul of his audience, he has inculcated his unflinching determination and adamant devotion in them. The constant use of "I" denotes his selfishness, pragmatism and sagacity, which can enable him to free the whole country from rampant chasms. But "I" in the following sentences sounds self-glorifying

- "I am the biggest cattle merchant in the state" (37)

- "Well, I have a practical scientific answer, not black magic and witchcraft, as some here may want to propose." (57)

- "As a businessman, I travel a lot and on my travel, I meet all kinds of people, that is how 
came to learn about reverse osmosis" $(59,60$, 61).

A close examination, reveals that the repeated use of "I" blending with the superlative "biggest" (34), the quantifier "a lot" (5) and the belittlement "not a black magic" (57) insinuates Lamang's swellness. He is boastful, which is a sign of megalomania. In his lack of humility his naughtiness and boastfulness depict him as a person who is superior to everybody on the earth.

Reversely, "we" and its anamorphous "us" and "our" (33.33\%) are self-redeeming examples as can be seen in the following sentences.

- "Our" greatest fear is that of drought (7).

- "We" can guarantee that never again would they have to worry about drought (10).

- Things like this are not impossible if we have the will and money. (73)

- This is the time to move our whole country and our people forward out of the dark ages (74).

These examples suggest that he and all his listeners are under the same flag and in the same boat. In this way, Lamang alertly shortens the distance between him and his audience, weakens the power and maintains at relationship of equality with them. This greatly helps to persuade the audience to share his proposal which is to take actions to overcome difficult situations. It is not needless to mention that the exclusive "we" which refers to "I and others" (the addresser and addressees) has not been used by Lamang since he is in campaign trail and has not got any team yet.

Last but not least, the third person pronouns and possessive adjectives in sentences such as "Ninety percent of our people in this local government are either full-time or part time farmers, and so their greatest fear, our greatest fear, is that drought", $(7,8)$ and "they would not have to worry about drought, like that of 1973" (11) are used to refer to those who are absent. By using "they" and "them", Lamang commiserates with other people who are suffering and invites the audience to feel the same.

\section{Overall Tenor of the Speech}

In all regards, the analysis of mood, modality and person deictic functions makes it possible to deduce the tenor of the discourse. Lamang is a candidate to state chairmanship election. He is the main participant in this extract and has presented his speech to his people in a bid to charm and persuade them. As the dominant speaker, he has wielded linguistic resources by choosing utterances that increase his power to control the discourse. The force of his interrogatives in: "but what if we assured the people that we could solve that?"(8), "But how can you do that?" (14) and imperatives in "Take water for instance"(3) "Don't tell me you will hire rainmaker" (15) "Look at me" (36), "think positive" (75) and suchlike shows that there is unequal power between him and his audience. The tenor of the discourse is that Lamang is the knower/expert while his listeners are considered the non-knowers or lay people. While he is speaking and persuading, the audience remains silent and listens to him as an omnipotent and omniscient being. There is low affective involvement between Lamang and his listeners. This is evidenced by himself in clauses (53, 54) "I can hear you asking, but how can he do that?". From this question one can sense out that the listeners consider Lamang as a boastful and megalomaniac politician who has been just using milky words to seduce them. Another corroborative evidence of low affective involvement is an avalanche of the use of the pronoun "I" (44, 44\%), which signals that Lamang reveals himself as an almighty, the beginning and end of everything. In trying to baffle his audience, he hides his humility. Thus, at the end of his speech, he has used the inclusive personal pronoun "we" and its anamorphous derivative "our" (33.33\%) to weaken his conceit and shorten or conceal the gaps between them and himself. There is infrequent contact between Lamang and his audience as shown in the following sentences "I travel a lot and on my travels I meet all kinds of people" $(59,60)$. This sentence presumes that Lamang is more famous abroad than at home and he is eager to share his experiences with his people if they elect him as the chairman of the state.

\section{CONCLUSION}

Overall, the study reveals a predominant occurrence of declarative mood $(74 \%)$ followed by command imperatives (16\%). The use of interrogative and exclamative is roughly negligible. This testifies that the excerpt is basically aimed at pouring both information and order on an audience barely hushed-off or reduced to silence. The modality analysis shows $60 \%$ of modulation and $40 \%$ of modalization, with the first strand functioning to express either unbending commitment and determination or obligation, while the second highlights that Lamang is a capable and suitable man to meet the audience's expectations. As to personal pronouns, the I-type is the most used $(44.44 \%)$ which shows that Lamang's speech is essentially self-centred. The "we" and "our" inclusive forms come next, ranking respectively $17.77 \%$ and $15.55 \%$; while the indexical "you" represents $13.33 \%$.

Definitely, this analysis proves that Lamang is an alert orator. As Wardhaugh [3], stresses "an effective communicator is one who is capable of getting others to dance with him, rather than against him. And not to get anyone to dance at all indicates complete failure." He has wittily handled language not only to drive his message home, but more importantly to dominate his audience. Lamang reveals himself as a charismatic orator before a submissive audience. 


\section{REFERENCE}

1. Crystal, D. (1985). How many millions? The statistics of English today. English Today, 1(1), 79.

2. Halliday, M. A. K., \& Webster, J. J. (Eds). (2009). Continuum Companion to Systemic Linguistics. Great Britain: MGP Books Group.

3. Wardhaugh, R. (1976). The Contexts of Language. USA: Newbury House Publishers, Inc.

4. Halliday, F. (1994). Rethinking international relations. Macmillan International Higher Education.

5. Halliday, M. A. K., \& Matthiessen, M. I. M. (2004/ 2014). Functional Grammar: An Introduction. $\left(4^{\text {rd }} \mathrm{Ed}\right)$. London \& New York: Taylor and Francis Group.

6. Eggins, S. (1994). An introduction to systemic functional grammar.

7. Fowler, R. (1986). Linguistic Criticism. Oxford: Oxford University Press.

8. Fan, W. (2002). Who is to Blame? Peking Foring Language Teaching and Research Press.

9. Ling, Y., Wang, G., Wheeler, D. A., Zhang, J. Z., \& Li, Y. (2011). Sn-doped hematite nanostructures for photoelectrochemical water splitting. Nano letters, 11(5), 2119-2125.

10. Wang, J. (2010). A Critical Discourse Analysis of Barack Obama's Speeches. Journal of Language
Teaching and Research: Finland: Academy Publisher, 1(3):254-261.

11. Ye, R. (2010). The Interpersonal Metafunction Analysis of Barack Obama's Victory Speech. In English Language Teaching. 3(2):146-151.

12. Ayoola, T. (2013). The effect of cashless policy of government on corruption in Nigeria. International Review of Management and Business Research, 2(3).

13. Al-sa'ati, N. M., \& Khalaf, A. (2013). A Critical Discourse Analysis of Obama's Political Speech at Cairo University. Unpublished Thesis: AlHabda' University college.

14. Taiwo, A. M., Harrison, R. M., \& Shi, Z. (2014). A review of receptor modelling of industrially emitted particulate matter. Atmospheric environment, 97, 109-120.

15. Yongbin, C. (2016) A Study of Interpersonal Function of Presidential Speeches, International Conference on Educational Research and Environmental Studies (EERES).

16. Houfei, Y. (2017). The Interpersonal Metafuntion Analysis of Barack Obama's Inaugural Address. International Journal of languages, Literature and Linguistics, 3(1):27-30.

17. Shakila, N. (2015). The International Journal of Social Sciences $30^{\text {th }}$ Janvier 2015. 30(1).

18. Hyland, K. (1998). Persuasion and context: The pragmatics of academic metadiscourse. Journal of pragmatics, 30(4), 437-455. 